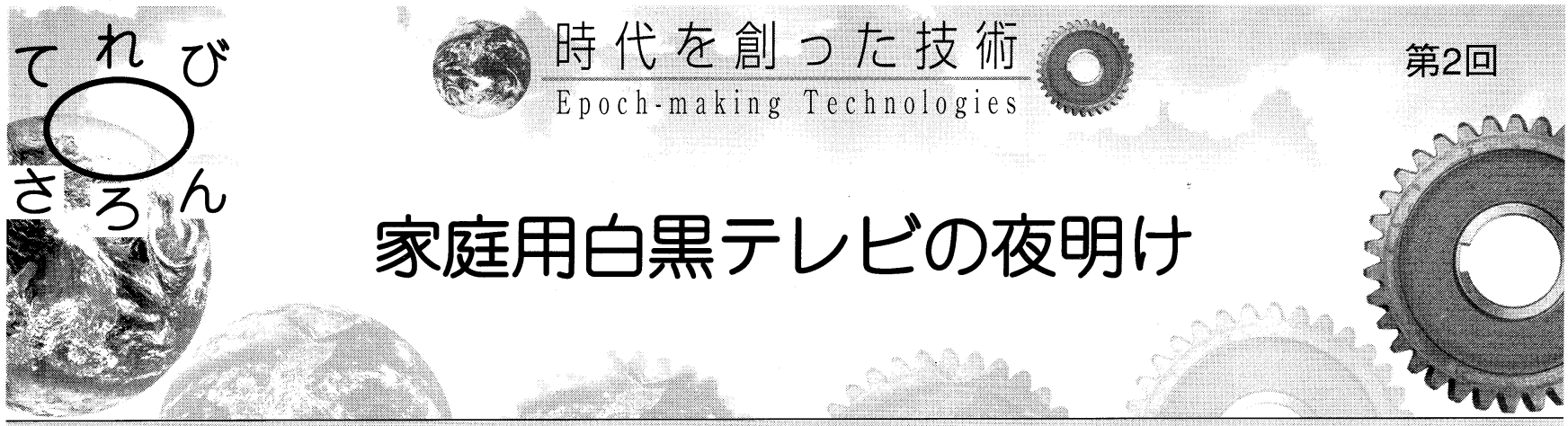

(故) 服部正夫氏の回顧録：「私の記録〜笹尾さんと私〜」より抜粋

キーワード：白黒テレビ，歴史

テレビジョンの開発は，わが国に おいても大正末期から，本会の創設 者で初代会長を勤められた（故）高 柳健次郎先生により行われており, 昭和11年には, ベルリン・オリンピ ックでテレビジョン放送に成功して いる.

その後，昭和 28 年 2 月のテレビジ ヨン本放送の開始に向けて，わが国 の電子機器メーカ各社が, テレビジ ヨン受像機の開発に躍起になってい たが，その中で最初に商品化に成功 したのが早川電機 (現シャープ)で あった。

今回，〈てれび・さろん>「時代 を創った技術」を企画するに当たり， シャープ広報室の前川洽治氏のご協 力により，国産第一号のテレビジョ ン受像機の商品化 (昭和 27 年暮れ商 品化）に携わられていた服部正夫氏 の回顧録を見出すことができた。こ の回顧録は，技術革新のすばらしさ の影に，䪊技術を実用化していく ための大変な課題に取組む先輩諸氏

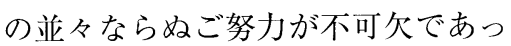
たことを，私たちに語っている。

この回顧録が，まさに本シリーズ の企画主旨と合致することから，そ の中から, 当会に関連の深い技術開 発の部分を（回顧録 23 章より）抜粋 し，紹介することとした。

揭載についてご快諾いただいた服 部正夫氏のご遺族であられるご長男 の服部 洋氏，ならびに，シャープ 株式会社の前川洽治氏に深く打礼申 し上げます。

(編集委員会 担当幹事)

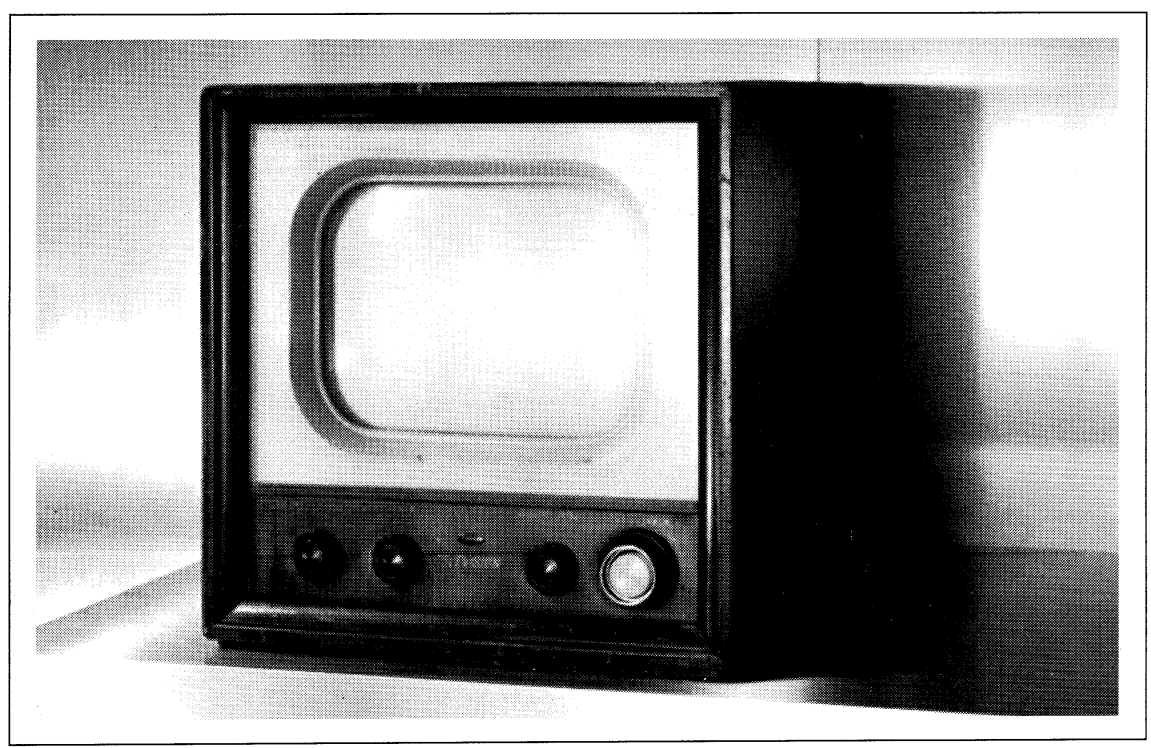

国産第一号のモノクロテレビ（シャープ（株）提供）

23. 経沢常務のテレビジョン 開発特命

ある日研究所に経沢常務が突然に来 られて，「おい君たち何して居るのか， 早くテレビを作れ」，とテレビジョン 開発の大号令が掛かりました。笹尾さ んはニコニコしながら私の所にきて君 がメインでやれと命じられました。し かし，現行の体制では能力不足で二鬼 を追うもの一鬼も得ずと，残念ですが， かなり開発が進渉していたテープレコ ーダーの開発は中断する事にしまし た，後日になってこのテープレコーダ 一の開発遅れを指摘されましたが, 止 むを得ないことでした。

24. 市場の反響とシャープの 取り組み

シャープは, 多年の念願であるテレ ビジョン企業化のGOサインがでて，
社內は活気に満ちていました.しかし， 無線業界の中には，喜ぶ前に余りにも 大きな問題だと, 戸惑いや慎重論が続 出したことは言うまでもありません。 それは次の事が原因ではなかったかと 思います。

1. 高価な商品で，当時 100 万円と も言われた価格で売れるのか.

2. 販売網をどうするのか, 生産販 売に伴う資金はどうするのか．

3. 故障した時のサービスをどうす るのか.

当時のラジオは数千円で販売され， 故障すると顧客が販売店に持ち込み修 理を依頼するのが通例でした，これに 対し, テレビ受像機は何十倍の価格で, 重量は20Kgと重く簡単に持ち運べる 物ではありません，又技術面から見て も技術革新とも言える全く新しい技術 に対し，販売網を含めた対応に大変苦 慮してしまいました。 
無線工業会でも，なにかと話題にな るテレビ事業化ついては，出席者の意 見はマチマチで，企業のトップにで意 見を聞く会を持つことになりました。 早速各企業のトップにで参集頂き意見 交換をしました。シャープは井上工場 長と私が出席し, 各社は松下幸之助氏 を始めとしてトップの方々が出席され ました．シャープは積極的なテレビの 企業化の推進について述べました，又 部品メ一カ一や管球メ一カ一は, 新し い部品の需要を期待して賛成でした。 しかし，肝心のセットメーカーからは いずれも慎重論が出て，この会議は結 論無と言う事で終わりました。

一方このテレビを利用するマスコミ 関係各社は，テレビの映像による報道 効果に大きな期待をかけ，テレビ事業 化には前向きでした，中でも読売新聞 社は，日本テレビ放送会社の設立計画 を待ち，標準方式は米国方式の採用を 推奨し，又放送機材やセットは輸入す れば良いと考えていたと思います。テ レビの普及についても，日本テレビ放 送会社が各地で実施した街頭テレビが 普及に大きな効果を上げたと思います

\section{5. テレビ受像機の準備体制}

笹尾さんは，テレビのGOサインが 出る前から，かねて頭の中にあつたシ ャープモノスコープ管とブラウン管2 本の試作を依頼しておられ，このブラ ウン管を使用してテレビ受像機の試作 を始めた訳です

受像機の試作に取り掛かって戸惑っ た事は，諸外国のテレビ技術の革新と も言える進歩は驚く事ばかりでした。 受像機の試作に当たつて, まず苦労し たのは見本も資料も無く，大学などに お尋ねしても教えてくれる人は皆無で した，最も参考になったのはアメリカ のテレビサービスマニアルでした

まず受像機の試作開始に当たって， 受像機を構成する部品の調査から始 め，その中で重要な部品を捜し出すこ とに集中し，又回路関係の技術につい ては, 水平垂直パルス鋸歯状波など， 全く新しい用語と新回路が続出して,
苦労の毎日でした，それでも今まで経 験した測定機器やオシロスコープの技 術など，又FM通信機器の経験などが大 変に役に立ちました．少しばかり新し い事が出来たと言えば，受像機の回路 は大方標準回路方式で試作されていま したが, シュープは最初からインター キャリヤー方式を採用したことです． この回路は割合と簡単で同期も安定し ていたので, それ以降, 各社共この回 路方式を採用し，長く続く事になりま した

\section{6. テレビ信号源とテレビ部品}

テレビ放送の無い時代にテレビを開 発するには，モノスコープ信号源は欠 かせないものでした。笹尾さんは，早 速自ら信号源を標準ラックに組み立て を開始されていました。仕事に行きづ まると，GHQの図書館に行き参考書 の調査です、調査した内容は早速取り 入れ，又部品で最も難しい偏向コイル は，日本橋で仕入れた米軍のレーダー 用を使用し，回路は何とか苦労の末信 号が出せるようになりました。

又受像機の方もこの信号源の信号を 受けて, 待望のテストパターンの映像 が映るようになり，この珍しいテレビ の映像をいち早く見ようと他部門から 見学者が急増しました。受像機の試作 を繰り返して見ますと, 次の三つの部 品が極めて重要であることが明らかに なってきました。

1. チューナー : 電波の入り口で超短 波の新部品で，性能と商品企画を 左右する

2. 偏向コイル : ブラウン管の電子銃を 偏向させるコイルで全く新部品.

3. フライバックトランス : ブラウン 管に高電圧を与える高電圧発生卜 ランス.

この三つの部品に的を絞り自社開発 し，自社生産したことが結果として他 社に先行出来たと思います。

昔のテレビ技術では, ブラウン管に 必要な高電圧を出すのに，トランスの 巻き上で行っていた為, 絶緑の関係で 家庭に持ち込める小型の受像機を作る
事はまず不可能とされていました。こ れを可能にさせたのはフライバックト ランスの発明で，当時の技術革新とも 言うべきものでした。このトランスは ドイツで発明された高圧発生回路で， 小型に出来て全く安全でかつ高い信頼 性があって，家庭に持ち込みできる小 型受像機になった事です，幸いにもこ のトランスは基本特許で無かったた め，利用者にとって幸いでした。

\section{NHK大阪の実験放送}

NHKは, 昭和26年関西地区で初め てテレビジョンPRを行うため, 大阪 NHK馬場町屋上より実験電波を発射 し，これを日本橋三越で受信し，NHK 技術研究所で試作した受像機で四日間 一般に公開することになりました。 シ ヤープでは早速研究所の屋上に巻き上 げ式10メートルのアンテナを建てその 日を待ちましたが，いかに受像機を調 整しても音は出るが映像は出す，雑音 に埋もれて画になりませんでした。早 速早川社長にお願しし，堂島の美津濃 ビルにおられるお知り合いの水野社長 に電話で場所の措借をお願いし，2台 程持ち込み受像実験をはじめますと， 電波も強く受像状況は全く良好で立派 な映像に大变満足したものです。

三越の一般公開は，珍しさもあって常 に満員で盛大でした，又シャープ独自 のこの受像実験は民間ではシャープが 初めてで，街では早速このシャープの 受像試験の成功の話題も流されました。

\section{8. 行政の配慮と輸入}

政府としても時代の要請として, 受 像機の見本は輸入を認めることになり ました. シャープも各種の見本を輸入 しましたが，又無線工業会でも東京と 大阪で各2台づつ輸入し，その内1台 は技術委員会で分解し部品の調查をし ました。

この頃になると，テレビジョンの標 準方式の討議が活発化して参りまし た. 特に読売新聞社の日本テレビは, 6メガの米国方式を提案し，無線工業 会は7メガを提案していました，結果 
として, 日本のテレビジョン標準方式 は非同期で6メガ方式が決定採用され た事はご承知の通りであります，又， CCIRの日本への国際電波割り当ては 最後まで残り，何チャンネルになるの か，周波数帯がどこに来るのか，チュ ーナ一の設定で悩むことが多かったも のです

受像機のブラウン管サイズはNHKが 7型，工業会が9型を提案していました が, シャープが14型を標準型とし量産 を進める内に，7型や9型の論議は自然 に消滅して行くことになりました。

\section{9. テレビ企業化の開発基本 方針}

昭和27年春に入り，来春からのテ レビジョン本放送予定が確実となり， シャープでは本放送に合わせたテレビ 販売を考え，テレビ量産の重要となる 部分の具体化を急いだものです．それ は次の3項目です．

1. 販売すべき標準型受像機の決定 之部品手配.

2. 重要部品の自社生産体制の確立. 「チューナー, 偏向コイル, フラ イバックトランス」です.

3. 営業とタイアップし, 講習会及 びサービス体制を確率。

生産販売する受像機は, 各機種共通 シャーシーとし，標準型は14型, 業 務用は 17 型の二機種とし, 最も重要 なブラウン管と真空管はRCA製を使用 する事として貿易部に輸入を依頼しま した，特に信頼性の面で当分は輸入で 進める事にしました。

チューナーは, チャンネル切り換え をロータリー方式で, 当面は7チャン ネルで設定し，試作課が量産金型を作 り, 重要な接点部品は純銀の接点を使 用しました.

偏向コイルは最も苦労した部品で す．このコイルを量産する機械はどん な機械を作れば良いか試作を繰り返す 内に，笹尾さんが，GHQの図書館で レーダーの文献を調查中に, 偏向コイ ルはコサイン巻という資料を見つけ， うまく巻線のできる機械を作りまし
た，後日笹尾さんがRCAを訪問された 時, 我々がコサイン巻を想像開発した 物と，全く同じ方法で制作していた事 に驚いたと回顧されていました。

フライバックトランスは, 工作課で 八ネカムコイルの量産型巻線機を製作 し，このコイルの絶縁に使用するパラ フィンは輸入品を使用しました，第3 項目の営業関係については記事も多く 別途に述べることにします

社内の部品製造については, 各担当 部門が引き受けて製造する事になり， 以上の各種の作業が一斉にスタートし たので社内も大変でした．

\section{0. 市況の反響に対応}

この頃になると、NHKで毎日実験放 送が行われるため，マスコミの報道も 含めてテレビの話題が日増しに増加し， 一般のユーザーのテレビに対する認識 が高まり, 販売にテレビの設置や購入 要望者が急速に増加してきました。

毎日営業を通じて受像機の貸し出し 要望が強く出されて，ついに30台ま ど受像機のテストを兼ねて制作するこ とにしました，又一方で，販売店に対 し説明会や講習会を開催すると, 常に 満員で, シャープの講習会は大变に評 判が良かったと思います。

この状況は今後のテレビ販売に対す る心配事は一掃されたようなもので， 後は最も重要な受像機の価格の検討に 入るようになりました。

当時の流通は，小売りの制度で，販 売店が電気製品の販売を一手に引き受 けていたため, テレビの購入要望は販 売店に集中する事になり，販売店は大 変良い顧客を多数抱えておられる事を 発見出来たことも大きな収穫でした。

\section{1. 一般部品の徹底改良}

テレビはラジオと比較して極超短波 を使用し，映像回路，高圧回路，など 新しい回路に加えて，使用電力も500 Wと, 大变異なった新しい部品を要求 されていました。当初に試作した受像 機の使用部品には，大半がラジオ用の 一般部品を使用し組み立てたのです
が，意外と故障が続出し，信頼性が極 めて低し事が判りました。

特に，抵抗，コンデンサー，電源SW， など断線や不具合などが続出し，部品 メ一カーに徹底的に改良を依頼するこ とになりました，その不具合は以降長 く続きサービスに大变手を取られまし た.これはテレビが全く新しい回路で あり，その回路に高周波やパルスを通 す事が原因で，この事が部品業界に新 しい技術革新を起こし，その後現在の 様に大きく発展する事になりました。

\section{2. テレビの特許と早川社長, 笹尾さんの渡米}

米国のテレビは, RCA社で研究開発 されたものが殆どで，重要回路部分は RCAの特許となっており，RCA社と 特許契約しなければ生産も販売も出来 ない仕組みになっていました。

昭和27年秋に入り，テレビの量産 を前にして，早川社長は笹尾さんを伴 い渡米され，ニューヨークのRCA本社 で特許契約を行い，又RCA社の各工場 を見学し, 今後のシャープの生産体制 の基礎を築かれました，その時のRCA 社の契約担当の方は, 極東支配人スト ラウス氏で，その後長くお付き合いす ることになりました。

笹尾さんは，テレビの情報と話題を 一杯もって帰朝され，その中でストラ ウス氏の言葉として米国では, テレビ を「世界の商品」と呼びます，これは百 年に一回しか来ない，又今後も百年間 続く商品で大事に育てて下さいと申さ れていました。

この早川社長の渡米は, 講和条約締 結の翌年で自ら企画されRCA社との契 約に出向かれた積極性に一同が敬服し たものです. 早川社長のユーモア溢れ る帰朝報告を皆で楽しく聞き，お元気 な姿を拝見して安心しました。

\section{3. 量産体制の確立とテレビ 工場の稼働}

昭和 27 年暮れになると，来春から のテレビ本放送に合わせた量産体制の 確立を，笹尾さんの帰朝報告を参考に 
して本社工場内に工場配置を完了し， 製造部の組織も12月に発令され，製 造第七課と命名されました。

年末には販売する受像機の価格も検 討され，14型で「175000円」と発表 されて，大きな反響をまきおこしまし た. 昭和28年の正月は, ラジオは勿 論の事, 各新聞社も全紙を使用してテ しビの夜明けを報道しました。

工場の量産ラインは, 部品の取り付 け, 配線台, 調整台, 組み立て, 仕上 げ, のブロックに別けて流れ作業とし， 生産規模は月300台〜500台を計画 しましたが, その数量はブラウン管に 制約される事になり, 当初の生産が営 業の要望に全く間に合わず, 毎日営業 に督促され大変でした。

\section{4. 組立て講習会}

組立講習会は, 販売店の店主店員に 対し技術の取得は勿論ですが，販売店 のテレビ販売に大きな安心感と自信を 与え, 又シャープにとっても販売店と のコミュニケーションやサービスのー 助となり, 販売政策上大变良い結果を もたらしました。

生産販売台数が上昇するにつれ, 講 習会用キットを生産し, 各地で新しい 放送局の開局がありますと, 優先的に キットをその地域に供給しました。講 習会の講師については, 多くは研究所 の方々にお願ししご苦労をかけました が, お陰で私も各地の講習会の講師を やらせてもらい, 全国の販売店主から 感謝されました。

\section{5. サービス体制の確立}

販売面で講習会がなされた為にサー ビス体制が大变作り易くなりました． 初めサービス組織は製造の夎下に変え ましたが, これにより品質情報を早く フィードバックすることが出来製品改 善に大いに役立ちました。

始めは製造ラインからもサービスマ ンを出しましたが, 生産台数が増加す るにつれ責任者をおいた組織とし，又 サービス要員の養成も同時に行い, 各 地に放送局の開局があれば, サービス
の要員もこの組織から派遣しました。 こうした経過を振り返って見ると, 当 初サービス体制作りで，テレビの故障 や顧客との応対にサービスが追従でき るかと不安でしたが, 比較的順調に進 められました。

尚サービスマンにはマナーが一番大 切と考え, その教育を徹底して行いま した. それはサービスマンが顧客の奥 座敷まで訪問するからです，毎朝服装 検査に靴下ハンカチの検査などから言 葉使いまで教育を徹底して行いまし た. お陰で帰りにはお土産を頂戴した り, 先方の自家用車で送られたりして， 結果として大変好評で話題はつきませ んでした，当時の交通は市電やバスで 能率が上がらず、溝手君が運転免許を 持っていたので, テストケースとして 自動車を導入したところ大变能率が上 がり, これがサービスカーの初導入と なり, 営業とタイアップして大きく発 展する事になりました。

\section{“おわりに”}

テレビ工場がスタートして6ヶ月ほ ど経過したある日, 笹尾さんがニコニ コしながら私の席にこられて, 今経理 の下の通路を通ったら佐伯さんが空か ら首をだして「おいテレビは儲かる． ガンバレ」と言われたと，最高の笑顔 を振り撒いて居られたのが, 今でも忘 れることが出来ません，この好業績で 受像機の価格を一気に3万円值下げし ました，その発表がなされますと，業 界も世間も大騒ぎとなり, 又証券市場 もこの成果と将来を期待し, シャープ の株価は最高値になりました。

昭和28年9月に, 経沢常務に同行し て私も米国及びヨーロッパの各国の大 手電機メーカーを訪問しました，特に 米国のRCA社の研究所, 部品工場, 製 造工場やサービス会社などを巡回し， 製造, 品質, サービスのノウハウなど を懇切丁寧に教わりました，そして翌 年には, 本格的な鉄筋了階建てのテレ ビ工場が建設され，新しい設備を導入 し新工場が完成しました。昭和29年 よりテレビの本格的な量産が新工場で
操業が開始されました。

この鉄筋テレビ工場の完成披露に は，各界の名士をお呼びして披露され ました，早川社長は挨拶の中で, 将来 性があって燃えない工場を作りまし た．安心して販売，購入してください と話され, 出席者一同から工場の規模 に驚きと称賛を得たものです，その後 シャープの西田辺の工場は4回に別け て次々と拡張された事は御承知の通り です。

早川徳次さんは, シャープペンシル の発明で知られ, 又大阪に定住の地を 求められた2年後, 大正 14年にラジオ 放送が開始された時, 最初にシャープ ダインのラジオを発売されました。笹 尾三郎さんは, 次世代となるテレビ開 発の要請を受け約束通り「世紀の商品」, テレビジョンを日本で最初に発売され ました，早川社長は，人間この世に生 まれたら必ず運」があると良く申され ました，それからすると，ラジオでも テレビでも日本で最初に発売できたの は幸運です。

又私も良い上司亡, 同僚部下に恵ま れ，大変「運」が良かったと深く感謝致 しております．今振り返って見ると， 「オッサン」は私の人生にとって, 公私 共に大変な師であったと改めて痛感し ております

以上, シャープの技術の流れを書い てみたいと思い筆をとりましたが, 結 果としてテレビが中心になりました. 在籍47年間の思うことが多すぎて， 経過の羅列になった事を深くお詫び致 します. 又その時々の関係の方に絶大 なご協力をいただき，なし得た事を皆 様に厚くお礼申しあげます。

（故）能部走走氏のシャープ時代のご略歴 大正8年1月 5 日卅. 1938年, 早川金属工業 (㧣) (現・シャープ (株)) 入社. 1961年, 電子機械研 究部長. 1963年, 無線事業部田辺工場長. 1968 年, 栃木事業部カラーテレビ工場長。1970年, テレビ事業部副本部長兼枋木工場長. 1972年, 総合開発本部副本部長兼商品開発研究部長を経 $\tau, 11$ 月, 取締役技術本部副部長兼家電開発研 究所長. 1973年, 取締役音響事業部長. 1979年, 常務取締役，音響システム事業本部長を経て， 6 月, 技術本部常務顧問. 1985年, シャープ(株) 退職. その後, 由淵電機 (株) 顧問. 